\title{
Cultural values in constructing moral worlds: Current debates and critiques on moral anthropology
}

\section{Ozan Can Yılmaz ${ }^{1 *}$}

${ }^{\prime}$ M.A. | Univiersity of Vienna, Department of Cultural and Social Anthropology, Vienna / AUSTRIA
* Sorumlu Yazar / Corresponding Author: Ozan Can Yılmaz E-posta: ozancan017@gmail.com

\begin{abstract}
Cultural anthropology shows a significant interest in the study of morality and ethics with its aim to understand the local contexts and human narratives. Actions and practices pertaining to the domain of morality create not only questions for cultural anthropologists to take into consideration but also immensely construct the social worlds in which the individual subjects for our anthropological inquiry are shaped. Considering how distinct cultural localities result in various ways in which morality is manifested and experienced, this article is concerned with current debates and critiques of moral anthropology as well as the essential function of cultural values within the anthropological study of morality.
\end{abstract}

Key Words: Cultural anthropology, moral anthropology, cultural values

\section{Introduction}

The distinctive contributions of the cultural anthropologists to the study of moral anthropology have been highlighted on the basis of the dominant approach to the "everyday ways in which morality and ethics are experienced, constructed, discussed, and lived, often tacitly, in particular ethnographic contexts" (Heim and Monius, 2014, p. 386). Regarding ethics as "the dimension of full range of human action or practice" (Lambek, 2010, p. 11), the embeddedness of morality in the practices of local contexts and in the narratives that human beings share are remarkably important, which leads us to the interpretative side of morality that varies across different cultural localities, and causes individuals to be shaped by their local social worlds resulting in various moral experiences (Heim and Monius, 2014). In the context of such dissimilar moral occurrences, I aim to discuss several current debates and critiques of moral anthropology with the subgoal to refer to the significance of cultural values in the anthropological study of morality as an emerging current debate. For this, I majorly refer to the texts of Didier Fassin and Carlo Caduff as well as the concepts of morality of reproduction and freedom suggested by sociocultural anthropologist Joel Robbins.

\section{Ahlâkî dünyaların inşasında kültürel değerler: Ahlâk antropolojisi üzerine güncel tartışmalar ve eleştiriler Öz}

Kültürel antropoloji, yerel bağlamlar ve insan anlatılarm anlama amacı ile ablâk ve etik araștırmalarna önemli bir ilgi gösterir. Ablâk alanma ilişkin eylemler ve uygulamalar, yalnız̧a kültürel antropologlarn dikekate almasi gereken sorular yaratmakla kalmaz, aym zamanda antropolojik araștırmamı için bireysel öznelerin şekillendirildiği sosyal dünyalar da büyük ölçüde inşa eder. Farkh külttürel yerel özelliklerin ablâkıın tezabür ettiği ve deneyimlendiği alanlara yansımasın inceleyen bu makale, ablâk antropolojisinin güncel tartışmalar ve eleştirilerinin yan sıra, ablâk antropolojisi çalişmalarndaki kültürel değerlerin temel işleviyle ilgilenmek.tedir.

Anahtar Sözcükler: Kültürel antropoloji, ablâk antropolojisi, kültürel değerler

\section{Anthropological reflexivity, detachment and the gaze}

In this section, I mainly refer to Didier Fassin's Introduction: Toward a Critical Moral Anthropology chapter in his A Companion to Moral Antbropology book to discuss the following points that have high relevancy in the critique of moral anthropology. To begin with, I would like to address the problems of the semantics that the term moral anthropology carries with itself, and then touch upon the historical implications on which the term comes across as problematic. Beyond the lexical implications of the term, I would also like to discuss the significant theoretical differentiation between the terms moral anthropology and the anthropology of moralities. It is then worth discussing how a moral or an ethical turn has taken place over time that put a different and significant emphasis on moral issues that were previously neglected; thus both the area of anthropological inquiry and the vocabulary it creates have been subject to a remarkable shift. Last but not least, I see it necessary to argue for an engaged positioning of an ethnographer, and discuss whether or not moral issues as the objects of study require a complete detachment of the subject, if such thing is ever possible. 
Exaltation of particular values and judgments not being the quintessential purpose of moral anthropology, it rather theoretically, epistemologically and practically shows interest in the study of moral tensions and debates by referring them as its objects of interrogation, and takes into account all the moral positions of all kinds. Thus, moral anthropology by no means comes across with a moralizing agenda into certain values. The proponents of a turn to ethics in anthropology argued for "the non-moralizing study of moral phenomena" as being one of their goals (Kapferer and Gold, 2018, p. 28). Therefore, anthropology is suggested to function toward exploring how societies and groups created their cultural distinction between good and evil, and how it is reflected in the everyday life of the agents (Fassin, 2008). However, it is suggested that the term "moral anthropology" is, in fact, disputable both semantically and historically. The semantical connotations the term carries imply a "do-gooder's anthropology" as well as an anthropology of the good. Moreover, the term has been considered to imply efforts to make the world a better place toward a normative concept of goodness (Fassin, 2012). Criticized as "formalist and universalizing" resembling eighteenth century philosophy, moral anthropology itself is thought to be moralist (Kapferer, Gold, 2018, p. 142-144). While the adjective "moral" itself could be explicitly normative, I would also consider the domain of moral philosophy in its attempt to work toward a virtuous act and if it could as well be reflected on the terrain of moral anthropology in the sense of attributing virtue to particular acts, values, and practices. Secondly, anthropologists were thought to take on the role of moral agents, and that anthropology has a certain moral commitment in its attempt to virtuously act, as Fassin explains it. Such aim toward the moral spheres of anthropology was well reflected in case of instances like the anthropological stance against oppression in favor of humanitarian rights, and formerly seen in the connection anthropologists had with the processes of colonization or imperialism (Fassin, 2012).

Another point worth mentioning is the distinctiveness between two terms: moral anthropology and anthropology of moralities. Apart from the lexical dividedness, the distinction is rather found in the theoretical argument. Fassin argues for the use of the adjective moral rather than the noun morality. In this regard, he suggests that the term morality delimitates the object of the anthropological inquiry whereas the other one suggests reflexivity of the anthropological inquiry.

Local moralities including local interpretations and configurations of norms and values are not the mere object for the anthropological study, and the discipline should not be narrowed down to local moralities when the inquiry reaches far beyond the localities of such norms and values. Therefore, the diversity and the vastness of human activity can also be considered when inquiring into the moralities, eliminating attempts to view local norms and values as distinct from the other spheres of human practices. Thus, the political, economic, social and religious considerations must be taken in such moral interrogations. The inquiry into how certain moral questions are raised and tackled also constitutes the interest of moral anthropology. In this sense, the moral categories contributing to our conception of the world around us, the morally arranged communities we collectively build, and the interrogation of the moral significance of particular actions and practices are the main dealings of moral anthropology. More interestingly, the formation of moral vocabularies is considered within the domain of moral anthropology in so much that they create a circulation of moral values, subjects, and injunctions that all together regulate the societal structures (Fassin, 2012, p. 4). In contrast to the cultural relativism and for Caduff the anthropological reflexivity being at the methodological heart of Fassin's outline of a moral anthropology (Caduff, 2011), I see it necessary to also consider the moral positioning of the anthropologist as the subject of inquiry, based on a critical account of a social world rather than a relativist description of it. Nonetheless, concerns over "analyzing ethnographic data through the lens of our own moral assumptions, traditions and concepts or falling into moralizing analysis" (Zigon, 2014, p. 746) were expressed. In the meanwhile, Caduff poses his critique of Fassin's argument for the critical analysis approach as an alternative to a rigid moral discourse carries with itself some problematic aspects including "the risk of reducing the purpose of moral anthropology to the empirical analysis of moral values in local context" (Caduff, 2011, p. 472). The disputable positioning of an ethnographer when applying critical analysis remains subject to critique as the extent to which a detached position in critical analysis should be differentiated from the classical perspective of cultural relativism, resembling Herskovits' version of cultural analysis of local systems of moral values (Caduff, 2011, p. 472).

On the other hand, when morality is taken as the object of anthropology, Fassin argues that it leads the anthropologist's moral stance to be neglected. In such an instance, the moral implications an anthropologist is making are obscured while moral anthropology takes into consideration the moral account of the anthropologist in its reflexive and descriptive structuring. Hence, I would like to raise the following question that was addressed by Fassin: Could we ever talk about attainment of a complete detachment from that which is being inquired? For Fassin, some moral involvement is "necessarily 
present" since it is again the human beings studying other human beings in an identical subject to object structure. Despite the cultural relativism anthropologist have been associated with, moral universalism has also been seen among anthropologists whether it to be criticizing racial discrimination or male domination, as argued by Fassin. Such argument of his reminds us that all human actions are motivated on moral assumptions, and therefore the research on humans. The social issues we seek to tackle quite naturally require sided positioning as the objects anthropologists deal with also demand some level of moral positioning (Fassin, 2008). Such positioning is circumscribed through our occupation in the field, interpretation of norms and values, and the style in which the writing takes place. Similarly, one interesting point that needs attention is the emergence of recent interest in moral issues. Fassin reminds us that violence, suffering, trauma, prisons, victims of wars and human rights were not among the issues anthropologists worked on several decades ago. Should we then say that these realities did not exist back then? This is certainly not the case, and there has been a remarkable shift in the gaze of the discipline together with an increasing moral positioning in such issues (Fassin, 2012).

\section{A priori vs. a posteriori assumptions}

The long-existing moral values that lie at the core of our common sense are not to be taken for granted but rather to be acknowledged as those values that are not commonly and collectively practiced across all societies, and as those principles that do not necessarily and innately belong with us. Hence, it is significantly relevant to refer to morality in its cultural and historical evolvement. It is to say that moral configurations have periodically been subject to tremendous shift to the extent that the moral order thought to be natural and virtuous to us could actually have been considered differently, and that the moral order might have been previously practiced differently. Such argument takes us to the claim of moral universalism and reminds us that the anthropological inquiry we ought to make is not to make judgments on what is good, truthful and virtuous but rather how these moral values are addressed and exercised. For this, a posteriori is much needed where the deduction of probable causes stem from experiences and observations. Thus, a priori approach in the social realm of morality being solely based on the "occasion of formal dilemmas" is considered to be replaced with an approach focusing on the moral "revealed in the course of action" (Fassin, 2012, p. 15). We are then left with finding out what it is truly meant by moral or ethical; is it futile to work toward a rigid definition of morality or gainful to ratify the validity of what ought to be the morally virtuous based on the prevailing actual practices?
In this regard, I would like to refer to the position of an ethnographer through whom his or her interpretations and descriptions of the agents' actions function as the basis of the meaning of moral and ethical. In such positioning of the ethnographer, he or she is then seen as a subject with certain ethical and moral stance. Fassin relates to this argument with his following statement: "One should not forget that the social sciences were born to distance the intellectual gaze from normative positioning" (Fassin, 2012, p. 15). Moreover, instead of an anthropological inquiry beginning with a priori assumptions, an inquiry into "what people do and say in everyday action and ordinary language to make sense of it a posteriori" is emphasized, which was explained in Veena Das' (2010) article, and therefore the apprehension of morality comes from an inquiry into actions and discourses as well as understanding these actions based on what the agents consider as morally acceptable and virtuous acts, as also argued in Toward an Ethic of the Act by Lambek (Fassin, 2012).

To conclude this section on the critique of moral anthropology, I would like to bring our attention to the suggested purpose of moral anthropology that is to prompt new areas of inquiry on the discourses and actions of humans and to create new ways to answer questions of morality and ethics. More importantly, it is to "unveil invisible stakes" to have a different view of the world (Fassin, 2012, p. 11). Together with the aim to provide a historical and cultural account of "the local sense of right and wrong" (Fassin, 2008, p. 336), a moral anthropology should aim to explore the cultural justifications that are used to defend certain discrepancies occurring between the desired and the practiced, and therefore such inquiry into the expectations and the actual happenings in the everyday lives of agents constitute a remarkable portion of an anthropological research (Fassin, 2008). Gradually moving toward the discussion on the cultural values in connection with moral anthropology, I would like to mention that "values have probably received less attention from anthropologists than from philosophers" as Fassin puts it, but yet values suggest some significant questions to consider such as "the interpretation of the role of culture in the shaping of moral values" (Fassin, 2012 , p. 11). The opposite is also equally valid for our consideration: What then is the role of morality in the formation of cultural values?

\section{The morality of reproduction vs. the morality of freedom}

I would like to begin this section by firstly referring to Robbins' conception and the rationale lying behind his attempt to associate cultural values with the anthropological study of morality. For him, the 
anthropological moralism collides with the ethical turn, and therefore he suggests to turn the good itself into an object of anthropological study. If then, the concept of the good is highly associated with cultural values, and how certain values are seen as good and desirable, we could easily link his suggestion for the anthropology of the good to why he connects the moral anthropology to the analyses of cultural values. For Robbins, the whole point for his suggestion "is not to define what might universally count as good but rather to explore the different ways people organize their personal and collective lives in order to foster what they think of as good" (Robbins, 2013, p. 457).

Contrary to Fassin's preference of the use of the term moral anthropology, Joel Robbins do not hesitate to use the term anthropology of morality, and therefore the noun morality in his concepts. Throughout this section, I refer to Robbins' Between Reproduction and Freedom: Morality, Value, and Radical Cultural Change and Cultural Values articles (Robbins, 2007, 2012), and link the current debates on cultural values to the arguments of moral anthropology that were previously made. Ultimately, I aim to highlight three major points within the intersectional analyses of all the reference texts I utilize in this article: Firstly, the inextricability of the concepts of the good and the desirable constituting the cultural values from the current debates on how the anthropological inquiry into the moral issues should be carried out. Secondly, it is essential to refer to the extent to which the ethnographer's unattainable detached positioning contributes to his or her descriptive or interpretive capability on the critical analysis of these values of good, desirable, and virtuous. Thirdly, it is distinctively important to consider the role of culturally constituted values in the processes of moral judgment-making, formations of particular moral stances of agents, and more importantly how the issues of morality can well be understood if the values are thoroughly analyzed. Robbins vividly accounts for the study of cultural values that have significance for the anthropological study of morality. It is for this reason that he refers to Kluckhohn's definition of good that was defined as a "cultural conception of that which is desirable" and that the good is defined "as that which is valuable" (Robbins, 2012,p. 117). Thus, his text suggests that morality within the domain of social life is better understood if the study of cultural values is considered. It should be noted that the traditional moral philosophy and recent anthropological studies on ethics/morality views moral experience as a means to realize the "good" (Zigon and Throop, 2014, p. 2). I would then like to suggest that collectively practiced actions function to be constitutive of grander cultural values. These common actions are the everyday manifestations of morality, and people are often obliged to make moral decisions between these actions that would align with both the collective and the individual sense of morality. Similarly, Robbins suggests two faces of morality as observed and practiced among the agents: the morality of reproduction and the morality of freedom (Robbins 2012, p. 117). Actions that are routine and performed based on everyday life are considered to be moral, and any kind of deviation from these routinized actions need justifications. The lack of performativity of these actions that "conforms to cultural expectations and meets the demands of cultural norms" (Robbins, 2012, p. 118) cause judgment by other group members. Therefore, Robbins suggests the term morality of reproduction for such routine actions and expectations because these actions constantly reproduce already existing patterns of thought, behavior, and sustain the cultural norms and values. Though with more emphasis on the agency, the moral stakes have remained high enough to constitute a vicious circle of routinized actions where the effect is formed by its cause, which I consider the whole process to be reflexive in its functional structure (118). In this sense, I would like to pose some arguments and points to consider in the light of Robbins' text and how certain values could be the main reason behind the existence of certain moral judgments and stances. The fact that confrontation to the cultural expectations in a given social life forms a cultural subschema through which confrontation is often implemented unnoticed, meaning a sense of the unconscious mode of acting toward the normativity of cultural values and expectancies is a significant point to consider in this matter. Moreover, the persistence and the stability in the implementation of such routinized actions are the backbones of the morality of reproduction; allowing people to consider themselves as moral agents properly functioning under the collective umbrella of their cultures. More interestingly, the level in which confrontation and actualization of these routinized actions are so high that it normalizes the very social order in which the order is constantly reproduced. Such automated reproduction continuum then functions as a hindrance for the agents themselves to come to terms with their cultural conflicts. In this regard, an attached and involved positioning of an ethnographer is much needed to critically analyze as a subject posing his or her moral stance by reflecting on the existing structures and construing the conditions of the object of the inquiry. The second face of morality proposed by Robbins, the morality of freedom, involves the sense of the agent and leaves the agents with the opportunity to decide for themselves. The moral decision that an agent is left with is often between conflicting or competing things, and the aspect of choice is a distinctive element in this 
second face of morality (119). Considering the emerging aspect of newer anthropological writing that puts more emphasis on agency over structures, the morality of freedom is said to attract more attention in the current times ${ }^{1}$. As the article of reference suggests, both sorts of moralities impact on the formation and sustenance of the social life, and one aspect of these two faces of morality should not be considered more important than the other.

Considering a monist approach, could we then talk about "a single account of the source of moral concern in both kinds of moral framework in any given society?" (Robbins, 2012, p. 119) and can we explore the extent to which the parts of social life is affected by these two modes of morality? While certain actions are made without much noticing or consciousness attached to them, the others require careful consideration allowing people to practice their freedom over what aspect of morality to adhere to. Both modes of moralities being deeply affiliated in cultural values, Robbin views these cultural values "to be those cultural conceptions that arrange other cultural elements (such as cultural ideas about persons, kinds of actions, things, etc.) into hierarchies of better and worse or more and less desirable" (Robbins, 2012, p. 120). For instance, I would like to suggest the phrase 'cleanliness is from faith', one that I was regularly exposed in my upbringing, and that is widely articulated among Muslims and a very common phrase in the Islamic countries has its implications on different hierarchical value spheres. In such an instance, the cultural value toward cleanliness is emphasized to exalt the religious value, and therefore it poses certain hierarchical conception toward different values. While the lack of cleanliness is collectively judged to such extent that the person is compared to infidels, the surplus of it is highly appreciated as a virtuous act. A similar instance to mine can be taken from Robbins' ethnographic work Becoming Sinners: Christianity and Moral Torment in a Papua New Guinea Society where the strong emphasis put on attaining a calm heart is associated to the value of gaining salvation, which stands out to be the highest value in Urapmin culture, an ethnic group in Papua New Guinea.

\section{The hierarchy of morality}

One interesting aspect of the hierarchical ordering of values is that when values are arranged into certain hierarchical structures, certain contradictions may also follow, which almost seems like there is no value consistency at all and that those who are in such value spheres seem to be not disturbed by such inconsistencies.

${ }^{1}$ For more example, see Laidlaw, 2002; Zigon, 2007 and Lambek, 2010.
This aspect of values concerns a highly valued practice that is put aside so that a more highly valued can be practiced. While Robbins provides examples from his ethnographic work among the Urapmin people, I would like to share a personal observation I made during my recent military service in Turkey, Istanbul. The highly conservative practice of changing clothes in the shower rooms stood out to me as both targeting at a higher value than its own value and yet inconsistently collision of values. One value that is quite gendered is that a male body culturally imposes no sexual meaning for another man; the male body should have no sexual implication for another man whatsoever. Moreover, this lays out a highly masculinized cultural value of male sexuality, that is the so-called "virtuous" heterosexuality in which there should practically be no shame when male bodies are exposed to one another. In such distinctiveness and detachment of male bodies from one another, however, male changing rooms suggest a different practice of a more higher value goal. In the context of a highly heteronormative society where homosexual practices, let alone homoerotic desires, are kept hidden from the public eye, men's conservative effort to hide his body parts, the genital area in particular, is aimed at a higher value. What could be the higher value behind such secretion and conservation of the body? Surprisingly, such practice is predominantly common among Muslims though there might be individual exceptions. It's so common that full nudity in front of other men is considered shameful, and that shame and honor are two of the highly revered and practiced values majorly in the Middle Eastern cultures. Thus, I suggest that the same men for whom a male body is nothing but merely a brother or a friend turn into a physical sphere to be conserved. In this context, the male genitalia serves to a higher value that is to protect bodily honor against shame, which ultimately has its roots in the religious values of the society. If men are too macho to have the slightest of homoeroticism, why then is the male body so severely conserved against another male body? While such conflicting value practice does not disturb the agents, it is also not considered as a failure of morality, furthermore, the standards and the everyday implementations of morality is well understood by looking at these hierarchical actualizations of certain cultural values. Such practice comes from its moral tie to the paramount value of shame and honor. The cultural value for the body ultimately gives the practice its moral relevance. Last but not least, we should be reminded that there are also hierarchical relations between values that are constitutive of the moral conceptions and judgments of a given society. At the foundation of the relationship between the cultures as structured by values and the anthropological study of 
morality lies the argument that "Moral action consists in carrying out a practice correctly in the right context such that appropriate values are realized" (Robbins, 2012, p. 122). It should also be noted that, as in the case of the aforementioned example, the morality of freedom is practiced in situations where it is unclear in which value sphere the agent should adhere to. With the emphasis on the people's choices over their actions into certain value spheres, there are certainly exceptional cases where the individual's concern over nudity, and therefore bodily shame, is lifted off because the person does not aim at a higher value goal.

\section{An ethnography into values organizing moral worlds}

In this section, I would like to use as an exemplary ethnography Ayala Fader's Mitrvah Girls: Bringing Up the Next Generation of Hasidic Jews in Brooklyn. Providing a detailed ethnographic study into the closed communities of Hasidic Jewish girls, Fader explores gender, the body, language, and how their socialization into a nonliberal culture takes place in a contemporary world. The study analyzes the major values that impact on the Hasidic culture, and how the freedom of reproduction is affected by certain values. Hasidic women stand out with their persistency on observing the religious commandments as a way to achieve and sustain the highest value their culture encourages for. Fader explains this culturally promoted value as the well-being of the Jewish people (Fader, 2009, p. 87). Both men and women work toward this highest value through strict religious observance, and more interestingly through the use of their vernacular. For instance, Hasidic men's use of Yiddish and lack of English fluency is a sign toward their dedication for sacred values separating them from Gentiles and women. In doing so, their ethnic distinctiveness is emphasized, which eventually helps them to preserve their sacred values. Moreover, Hasidic women's adoption of Yiddish intonation while speaking English functions as a distinctive element that connects them to their values on a daily basis (Fader, 2009). Such linguistic distinctions from the contemporary world outside is a means to daily realize the community's moral practice, and the moral issues of the community are immensely associated with those cultural and religious values Hasidic Jews hold high esteem for (Robbins, 2012).

Before the concluding remarks, I would like to discuss two aspects of cultures: pluralist vs. monist cultures. Robbins mentions Dumont's anthropological theory of value in which societies are structured based on paramount values, and that these superior values arrange the relations between all other values (Robbins, 2012). Though the culture, and therefore the values, may change over time, it is argued that the society would inevitably work toward creating paramountcy and monism of values, which then become the norm. Considering Robbins' argument of how monist value approach and a single paramount value system fell from favor, he notes that there is still not a well-established anthropology of pluralism, and a disinterest in cultural values and an emphasis on the individual's preference on values have come to the fore. He goes on to argue that "one would expect that truly monist cultures would present their members with relatively fewer situations in which the morality of freedom is in play, whereas pluralist ones would likely offer fewer opportunities for the morality of reproduction" (Robbins, 2012, p. 130).

\section{Concluding remarks}

All along the previous sections, I had in mind to highlight the argument that if the anthropological inquiry aims toward a critical analysis on moral issues, more comprehensive attention to the cultural values must be given. In doing so, the morality of reproduction and freedom present in societies both separately and simultaneously can be detected through a wider analysis on the role of the cultural values in shaping the moral worlds. Considering the vastness and the variety of people's experiences on moral issues, we could also have a better understanding of the pluralist value systems that are constitutive of diverse and multi-dimensional moral worlds. From the reproductive function of morality with people aiming for absolute moral purposes to more multifaceted practices toward fewer concerns over having single value conceptions, both the intermingled and the hierarchical statuses of cultural values remind us of the divergent ontologies exist beyond our monist judgments. Suggesting a turnaround instead of being firmly established on a single framework for the analysis of morality, Martin Holbraad (2018) refers to this diversity/plurality in his article Steps Away from Moralism as "The idea would be to use the diversity of these materials to unsettle the analytical framework in question" (Kapferer and Gold, 2018, p. 44). Within the understanding of even a strict moral orientation is arranged by various moral order, and considering "the multitude of everyday experiences, noticed and unnoticed, that shape our habitual ways of being in the world, our comfortable fidelity to a particular form of life" it can be confidently asserted that it is indeed plurality that shapes the moral experience (Zigon, 2014, p. 12).

\section{References}

Caduff, C. (2011). Anthropology's ethics. Moral positionalism, cultural relativism, and critical analysis. Anthropological Theory, 11(4), 465-480. https://doi. org/10.1177\%2F1463499611428921 
Das, V. (2010). Engaging the life of the other: Love and everyday life. In M. Lambek (ed.), Ordinary ethics: Anthropology, language, and action (pp. 376-399). Fordham University Press.

Fader, A. (2009). Mitzvah girls: Bringing up the next generation of hasidic Jews in Brooklyn. Princeton University Press. https://doi. org/10.1515/9781400830992

Heim, M., and Monius, A. (2014). Focus on recent work in moral anthropology. Journal of Religious Ethics, 42(3), 385-392. https://doi.org/10.1111/jore.12062

Holbraad, M. (2018). Steps away from moralism. In B. Kapferer and M. Gold (eds.), Moral anthropology: A critique (pp. 27-48). Berghahn Books. https://doi.org/10.2307/j.ctvw04hdc.4

Fassin, D. (2008). Beyond good and evil?: Questioning the anthropological discomfort with morals. Anthropological Theory, 8(4). 333-344. https://doi.org/10.1177/1463499608096642

Fassin, D. (2012). Introduction: Toward a critical moral anthropology. in D. Fassin (ed.), A companion to moral anthropology (pp. 1-19). John Wiley \& Sons, Inc. https://doi. org/10.1002/9781118290620.ch

Kapferer, B., and Gold, M. (eds). (2018). Moral anthropology. A critique. Berghahn Books. https://doi.org/10.2307/i.ctvw04hdc

Kluckhohn, C. (1962). Values and value-orientations in the theory of action: An exploration in definition and classification. In T. Parsons and E. A. Shils (eds.), Toward a general theory of action: Theoretical foundations for the social sciences (pp. 388-433). Harper \& Row. (Original work published in 1951).

Laidlaw, J. (2002). For an anthropology of ethics and freedom. Journal of the Royal Anthropological Institute, 8(2), 311-332. https://doi.org/10.1111/1467-9655.00110

Lambek, M. (2010). Introduction. In M. Lambek (ed.), Ordinary ethics: Anthropology, language, and action (pp. 1-36). Fordham University Press.

Lambek, M. (2010). Toward an Ethic of the Act. In M. Lambek (ed.), Ordinary ethics: Anthropology, language, and action (pp. 3963). Fordham University Press.

Robbins, J. (2004). Becoming sinners: Christianity and moral torment in a Papua New Guinea society. University of California Press. https://doi.org/10.1525/9780520937086

Robbins, J. (2007). Between reproduction and freedom: Morality, value, and radical cultural change. Ethnos, 72(3), 293-314. https://doi.org/10.1080/00141840701576919

Robbins, J. (2012). Cultural values. In D. Fassin (ed.), A companion to moral anthropology (pp. 115-132). John Wiley \& Sons, Inc. https://doi.org/10.1002/9781118290620.ch7

Robbins, J. (2013). Beyond the suffering subject: Toward an anthropology of the good. Journal of the Royal Anthropological
Institute. 19(3), 447-462. https://doi.org/10.1111/1467$\underline{9655.12044}$

Zigon, J. (2007). Moral breakdown and the ethical demand: A theoretical framework for an anthropology of moralities. Anthropological Theory, 7(2), 131-150. https://doi. org $/ 10.1177 \% 2 \mathrm{~F} 1463499607077295$

Zigon, J. (2014). An ethics of dwelling and a politics of worldbuilding: A critical response to ordinary ethics. Journal of the Royal Anthropological Institute, 20(4), 746-764. https://doi. org/10.1111/1467-9655.12133

Zigon, J., and Throop, C. J. (2014). Moral experience: Introduction. Ethos, 42(1), 1-15. https://doi.org/10.1111/etho.12035

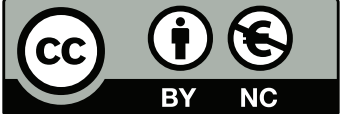

2020. Author(s)

This work is an open access article published under Creative Commons AttributionNonCommercial (CC BY-NC 4.0) license. 